\title{
Pengembangan bahan ajar eksperimen fisika berbasis video based laboratory menggunakan wahana permainan taman kanak-kanak pada materi mekanika
}

\author{
Syam Mustika Aisya \\ Program Studi Pendidikan Fisika, FKIP, Universitas Ahmad Dahlan \\ Jl. Ringroad Selatan, Tamanan, Banguntapan, Bantul, Daerah Istimewa Yogyakarta \\ Surat-e: syammustikaaisya@gmail.com \\ Ishafit \\ Program Studi Pendidikan Fisika, FKIP, Universitas Ahmad Dahlan \\ J1. Ringroad Selatan, Tamanan, Banguntapan, Bantul, Daerah Istimewa Yogyakarta \\ Surat-e: ishafit@pfis.uad.ac.id
}

\begin{abstract}
Pada umumnya dalam pembelajaran fisika lebih baik belajar memahami dari pada menghafal konsep-konsep karena bukan hanya teori saja akan tetapi juga ada eksperimen yang dilakukan untuk membantu siswa dalam memahami materi yang diberikan guru di kelas. Pada penelitian ini dibuat bahan ajar yang membuktikan bahwa penerapan fisika dalam kehidupan sehari-hari akan terbukti secara nyata dengan langkah-langkah eksperimen berbasis Video Based Laboratory. Langkah ini membantu siswa dalam memahami proses pembelajaran di kelas mengenai pokok bahasan mekanika gerak. Metode yang digunakan adalah Research and Development dengan model 4-D terdiri dari empat langkah yaitu pendefinisian (define), perencanaan (design), pengembangan (develop), dan penyebarluasan (Disseminate). Produk yang dikembangkan telah diujikan pada siswa kelas XI di SMA Negeri 5 Yogyakarta, dengan instrumen berupa angket kelayakan. Hasil penelitian pengembangan bahan ajar berupa buku panduan eksperimen fisika berbasis video based laboratory menggunakan wahana taman kanak-kanak dan CD sebagai bahan eksperimen mendapat penilaian dari validator ahli materi $88 \%$, validator ahli media sebesar $83,6 \%$, dan hasil uji lapangan terhadap siswa 83,79\%. Berdasarkan hasil tersebut, bahan ajar yang dikembangkan dikategorikan sangat layak untuk digunakan sebagai bahan ajar.
\end{abstract}

In most cases, it is to understand than memorize in physics learning. It is because not only a theory but also an experiment to help students understanding the subject given by the teacher. For this research, it uses a teaching content that proves the application of physics in daily life will be proven visibly through experiment steps based Video based laboratory. This step helps the student to understand the process of learning about the chapter on motion mechanics. The method of this research is RND with 4-D model. The 4-D model consists of 4 steps, those are define, design, develop, disseminate. The product that will be developed has been tested by the students in the 12 grade in SMAN 5 Yogyakarta with feasibility questionnaire. The experimental result of the developing teaching content is physics experiment guidebook based video-based laboratory using kindergarten's playground and $\mathrm{CD}$ as experimental material to get a rating from the validator. It gets $88 \%$ from a content expert validator, $83,6 \%$ from a media expert validator, the field test result for student get $83,79 \%$. Based on the result, the teaching content that has been developed is categorized as very decent to be used as a teaching content

Kata kunci: Bahan Ajar, Mekanika, Video Based Laboratory

\section{Pendahuluan}

Dalam melakukan aktifitas sehari-hari kita tidak terlepas dari fenomena alam termasuk fenomena fisika, bahkan di taman kanak-kanak yang sering kita jumpai terdapat banyak wahana yang menggunakan prinsip dasar fisika. Namun sering kali kita enggan memperhatikan gejala alam tersebut secara mendalam. Sebenarnya, pembelajaran fisika yang dipelajari sekolah kadangkala 
mempelajari fisika secara matematis tanpa ada pemahaman konsep sesungguhnya dengan menerapkan dalam kehidupan sehari-hari secara langsung. Hal tersebut dapat terjadi karena dalam proses pembelajaran fisika tidak ada kegiatan praktek secara langsung untuk memahami materi yang diberikan di kelas.

Pada umumnya dalam pembelajaran fisika lebih baik belajar memahami dari pada menghafal konsep-konsep karena dalam pembelajaran fisika bukan hanya teori saja akan tetapi juga ada eksperimen yang dilakukan untuk membantu siswa dalam memahami materi yang diberikan guru di kelas. Eksperimen yang dilakukan di dalam kelas hanya eksperimen secara demonstratif belum menuju eksperimen dengan pengambilan data secara nyata sehingga siswa sulit mempelajari fisika dalam kehidupan sehari-hari.

Banyaknya sarana teknologi yang ada di sekolah seperti adanya komputer dan internet yang dapat digunakan oleh siswa. Akan tetapi, siswa hanya menggunakan dalam bentuk kegiatan di luar pembelajaran saja diantaranya sebagai alat media sosial. Pengetahuan siswa terhadap penggunaan teknologi sebenarnya mempunyai nilai yang tinggi namun fasilitas yang diberikan tidak digunakan sebagaimana mestinya yaitu digunakan sebagai sarana pembelajaran. Dalam pembelajaran eksperimen fisika dikenal eksperimen berbasis Video Based Laboratory, eksperimen tersebut memanfaatkan komputer sebagai alat eksperimen dan menggunakan video sebagai bahan. Eksperimen berbasis Video Based Laboratory menggunakan perangakat lunak yang dapat diunduh secara gratis yang digunakan sebagai alternatif eksperimen fisika dengan pengambilan data secara nyata. Salah satu contoh materi eksperimen fisika berbasis Video Based Laboratory adalah pada pokok bahasan materi mekanika seperti pada wahana taman kanak-kanak [1].

Bahan ajar fisika yang digunakan oleh guru maupun siswa di sekolah belum sampai menuju bukti bahwa pembelajaran fisika pada pokok bahasan mekanika gerak belum terdapat data secara nyata yang menunjukkan data tersebut sesuai dengan penerapan konsep fisika. Contohnya pada teori gerak osilasi pendulum yang dapat diaplikasikan pada kehidupan sehari-hari seperti ayunan yang mana belum ada data yang membuktikan bahwa ayunan tersebut sebagai salah satu penerapan dalam osilasi pendulum. Pada penelitian ini akan dibuat bahan ajar yang membuktikan bahwa penerapan aplikasi dalam kehidupan sehari-hari akan terbukti secara nyata dengan langkah-langkah eksperimen berbasis Video Based Laboratory sehingga dapat membantu siswa dalam memahami proses pembelajaran di kelas mengenai pokok bahasan mekanika gerak.

\section{Kajian Pustaka}

\section{Bahan Ajar}

Bahan ajar adalah segala bentuk bahan yang digunakan untuk membantu guru atau instruktur dalam melaksanakan proses pembelajaran di kelas [2]. Bahan ajar disusun secara sistematis baik tertulis maupun tidak, yang menampilkan sosok utuh dari kompetensi yang akan dikuasai siswa dan digunakan dalam proses pembelajaran. Contohnya, seperti buku pelajaran, modul, handout, LKS, model atau market, bahan ajar audio, bahan ajar interaktif, dan sebagainya. Sehingga tercipta lingkungan atau suasana yang memungkinkan siswa untuk belajar [3].

\section{Buku Panduan Eksperimen}

Buku panduan eksperimen adalah buku yang memuat prinsip, prosedur, deskripsi materi pokok, atau model pembelajaran yang digunakan oleh para pendidik dalam menjalankan tugas pokok dan fungsi sebagai pendidik [4].

Buku panduan eksperimen merupakan buku yang disusun sebagai petunjuk kegiatan eksperimen yang mempunyai aturan standar dan disusun oleh para pakar dalam bidangnya yang terdapat maksud dan tujuan intruksional yang dilengkapi dengan sarana-sarana pengajaran yang serasi dan mudah dipahami oleh pemakainya. Secara garis besar buku panduan eksperimen memuat berbagai hal yang berkaitan dengan kegiatan eksperimen, dasar teori, alat dan bahan yang digunakan di percobaan, prosedur kerja, lembar dan pengamatan dan sebagainya.

\section{Wahana Permainan Taman Kanak-Kanak}

Dalam ilmu fisika wahana permainan pada taman kanak-kanak, seperti ayunan, perosotan, jungkat-jungkit, mangkok putar, dan yang lainnya dapat dijadikan sebagai contoh aplikasi dalam kehidupan sehari-hari pada pembelajaran fisika. Karena tujuan utama semua sains termasuk fisika, umumnya dianggap merupakan usaha untuk mencari keteraturan dalam pengamatan manusia pada alam sekitarnya [5]. Berikut beberapa contoh wahana permainan yang berada pada taman kanak-kanak serta gejala fisika yang terdapat pada wahana permainan tersebut.

\section{1) Gerak harmonik sederhana pada ayunan}

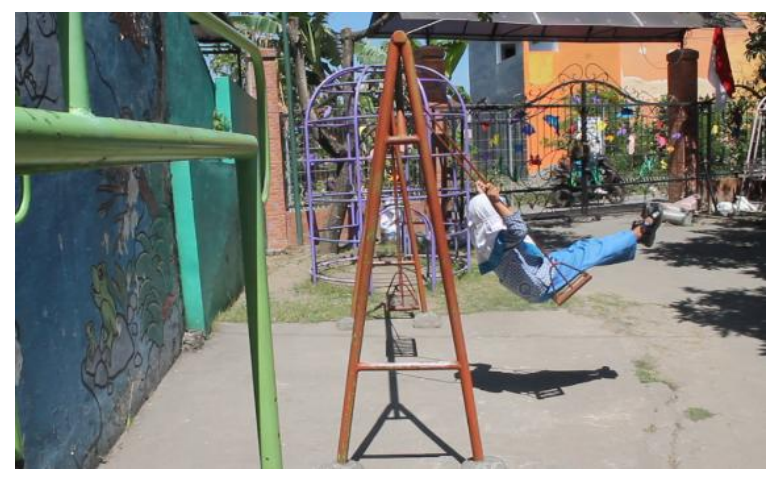

Gambar 1. Wahana permainan ayunan

Pada wahana permainan ayunan terdapat beberapa gejala fisika yang terjadi pada geraknya yaitu gerak 
harmonik sederhana pada bandul dan terdapat energi pada gerak harmonik.

\section{a) Gerak harmonik sederhana pada bandul}

Ayunan bandul (pendulum) merupakan salah satu fenomena dalam pelajaran fisika yang menunjukkan gerakan osilasi [6]. Osilasi dapat didefinisikan sebagai gerak bolak-balik suatu benda yang terjadi secara periodik atau berkala yaitu gerak benda tersebut berulang pada selang waktu yang tetap [7]. Sebuah karakteristik penting dari gerak osilasi adalah frekuensinya atau banyaknya osilasi yang terselesaikan setiap sekon. Besaran yang berkaitan dengan frekuensi adalah periode gerak yaitu waktu yang diperlukan untuk menyelesaikan satu osilasi (atau siklus). Artinya [8].

$$
T=\frac{1}{f}
$$

atau

$$
f=\frac{1}{T}
$$

Dalam buku Fisika Untuk Sains dan Teknik Jilid 1 menyatakan gerak bandul merupakan gerak harmonik sederhana hanya jika amplitudo gerakannya kecil. Gambar 2 memperlihatkan bandul sederhana yang terdiri dari tali dengan panjang $L$ dan beban massa $m$ [9].

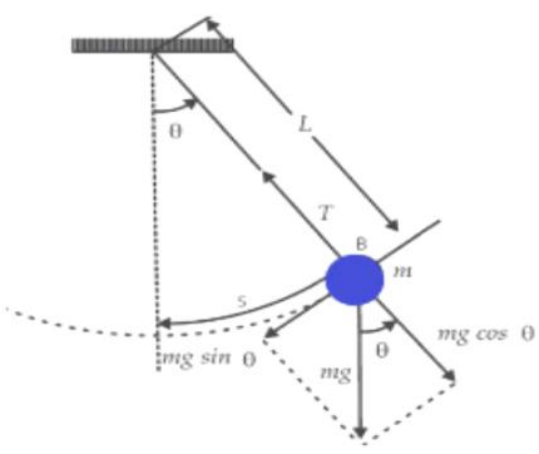

Gambar 2. Osilasi gerak bandul [9].

Gaya yang bekerja pada beban adalah beratnya $m g$ dan tegangan $\mathrm{T}$ pada tali. Bila tali membuat sudut $\theta$ terhadap vertikal, berat memiliki komponen-komponen $m g \cos \theta$ sepanjang tali dan $m g \sin \theta$ tegak lurus tali dalam arah berkurangnya $\theta$. Misalkan $s$ sebagai panjang busur diukur dari dasar lingkaran. Panjang busur dihubungkan ke sudut $\theta$ oleh

$$
s=L \theta
$$

Komponen tangensial percepatan benda adalah $d^{2} s / d t^{2}$. Komponen tangensial hukum kedua Newton adalah

$$
\sum F_{t}=-m g \sin \theta=m \frac{d^{2} s}{d t^{2}}
$$

atau

$$
\frac{d^{2} s}{d t^{2}}=-g \sin \theta=-g \sin \frac{s}{L}
$$

Jika $s$ jauh lebih kecil daripada $s / L$, sudut $\theta=s / L$ adalah kecil, dan kita dapat mendekati sin $\theta$ dengan sudut $\theta$. Dengan menggunakan $\sin (s / L) \approx s / L$ dalam persamaan (4), kita akan memperoleh

$$
\frac{d^{2} s}{d t^{2}}=-\frac{g}{L} s
$$

Gerak bandul dengan demikian mendekati gerak harmonik sederhana untuk simpangan kecil. Persamaan (5) dapat ditulis

$$
\frac{d^{2} s}{d t^{2}}=-\omega^{2} s
$$

Persamaan (6) merupakan persamaan diferensial dengan solusi sebagai berikut:

$$
x(t)=A \sin (\omega t+\phi)
$$

atau

$$
x(t)=A \cos (\omega t+\phi)
$$

Percepatan gravitasi dengan mudah dapat diukur dengan menggunakan bandul. Persamaan gravitasi $g$ yang diperoleh [9].

$$
g=\frac{4 \pi^{2} L}{T^{2}}
$$

\section{b) Energi pada gerak harmonik sederhana}

Gerak harmonik sederhana dapat dipelajari lebih lengkap dengan pertimbangan-pertimbangan energi. Hukum Kekekalan Energi Mekanik mengatakan bahwa: "Pada getaran harmonik terjadi pertukaran energi potensial menjadi energi kinetik atau sebaliknya, tetapi energi mekanik, yaitu total energi potensial dan energi kinetik tetap" [10]. Energi kinetik adalah energi yang terdapat pada setiap benda yang sedang bergerak.

$$
E_{k}=\frac{1}{2} m v^{2}
$$

Sedangkan energi potensial adalah energi yang dimiliki suatu benda karena posisi nya atau keadaannya yang menunjukkan bahwa usaha atau kerja dapat dilakukan. Secara matematis, energi potensial gravitasi persamaannya sebagai berikut:

$$
E_{p}=m g h
$$

Energi mekanik adalah penjumlahan energi kenetik dan energi potensial

$$
E_{m}=E_{p}+E_{k}
$$




\section{2) Bidang miring pada perosotan}

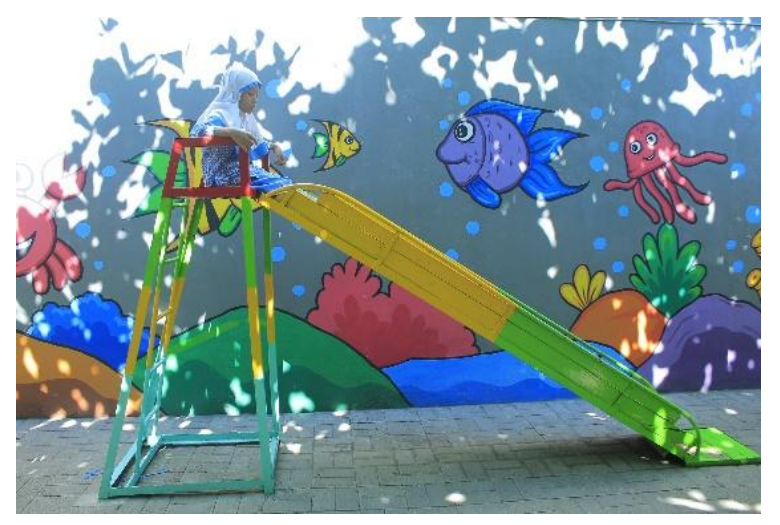

Gambar 3. Wahana permainan perosotan

Pada wahana permainan perosotan terdapat beberapa gejala fisika antara lain:

\section{a) Gaya gesekan}

Gaya gesekan termasuk gaya sentuh, yang muncul jika permukaan dua benda bersentuhan langsung secara fisik, gaya ini memilki arah yang berlawanan dengan arah gerak benda dan searah dengan permukaan bidang sentuh [11]. Secara umum, gaya gesek suatu benda dapat digolongkan dalam dua jenis, yaitu gaya gesek statik $(f s)$ dan gaya gesek kinetik ( $f k)$. Gaya gesek statik yaitu gaya gesek yang berkerja pada benda dalam keadaan diam, sedangkan gaya gesek kinetik yaitu gaya gesek yang bekerja pada benda dalam keadaan bergerak.

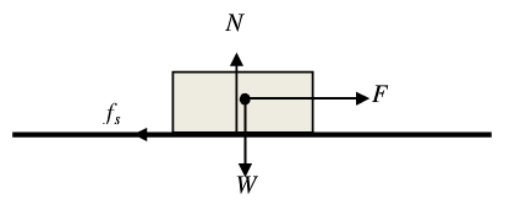

Gambar 4. Benda di atas permukaan membentuk gaya gesek [11].

Gaya gesek yang dihasilkan mempunyai tiga karakteristik [8].

1) Jika nilai $F<f s$, maka balok dalam keadaan diam, maka $f s$ dan komponen dari $F$ yang sejajar dengan permukaan bernilai sama, dan $f_{s}$ berlawanan arah dengan komponen $F$ itu.

2) Jika nilai $F=f s$, maka balok tepat saat akan bergerak, maka

$$
f_{s}=\mu_{s} N
$$

3) Jika nilai $\mathrm{F}>f s$, maka balok bergerak dan gaya gesekan statik $f s$ akan berubah menjadi gaya gesekan kinetik $f k$. yang ditentukan oleh

$$
f_{k}=\mu_{k} N
$$

\section{b) Benda pada bidang miring}

Misalkan sebuah benda diletakkan pada sebuah permukaan kasar yang miring relatif terhadap horizontal, seperti ditunjukkan pada gambar 5. Untuk menganalisisnya, gaya yang bekerja pada benda adalah gaya gravitasi $m g$, gaya normal $N$, dan gaya gesek statik fs.

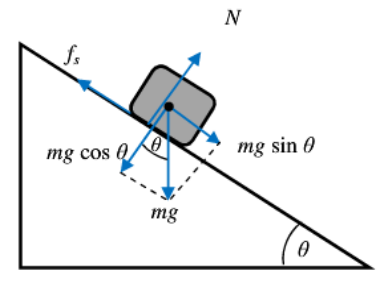

Gambar 5. Benda di atas permukaan miring mengalami beberapa gaya [11].

Gaya normal $(N)$ pada bidang miring bernilai:

$$
N=w \cos \theta=m g \cos \theta
$$

Sedangkan koefisien statik persamaannya adalah

$$
\mu_{s}=\tan \theta_{c}
$$

Ketika sudut yang diberikan benda melebihi sudut kritis atau $\theta \geq \theta_{c}$ benda akan begerak dipercepat ke bawah bidang miring dengan gaya gesek kinetik $f k$ seperti pada persamaan (14). Sehingga gesek statik $f s$ dari persamaan (13) dimasukkan persamaan $f k$ menjadi [12].

$$
\mu_{k}=\tan \theta_{c}-\frac{a}{g \cos \theta}
$$

\section{c) Energi}

Ada bermacam-macam bentuk energi, antara lain energi mekanik, energi cahaya, energi listrik, dan energi nuklir. Dalam hal ini akan dibahas tentang energi mekanik yang terdiri dari energi potensial gravitasi bumi pada persamaan (11) dan energi kinetik pada persamaan (10). Hukum kekekalan energi mekanik menyatakan "jumlah energi potensial dan energi kinetik suatu benda selalu konstan, selama tidak ada gaya luar yang mempengaruhinya" [13].

\section{3) Gerak melingkar pada mangkok putar}

Pada wahana permainan mangkok putar (gambar 6) terdapat beberapa gejala fisika antara lain besaran fisis pada gerak melingkar beraturan: 


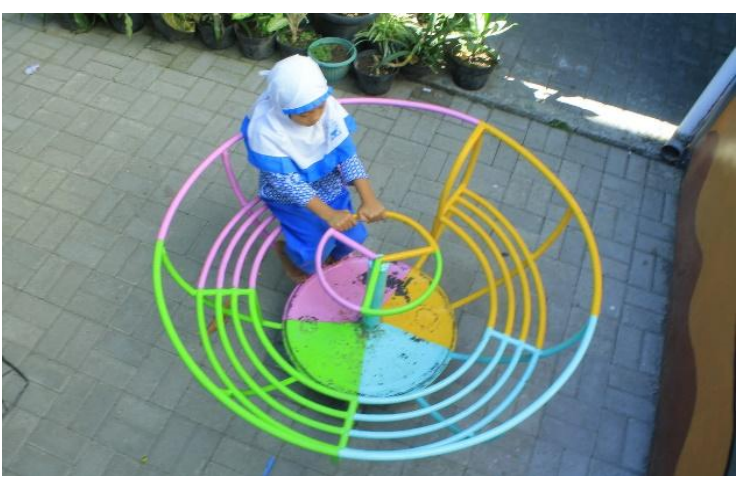

Gambar 6. Wahana permainan mangkok putar

\section{a) Besaran sudut}

Pada gambar 7, sebuah partikel yang bergerak mengelilingi sebuah lingkaran dengan jari-jari $r$. Secara umum besaran sudut dituliskan sebagai berikut:

$$
\theta=\frac{s}{r}
$$

dengan, $\theta$ merupakan besaran sudut ( $\mathrm{rad}), s$ adalah panjang busur lingkaran (m), dan $r$ adalah jari-jari lingkaran (m)

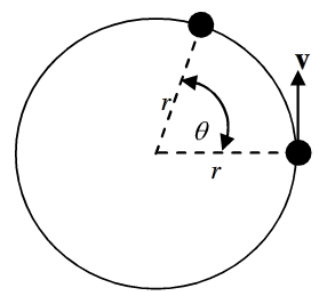

Gambar 7. Partikel bergerak sejauh s pada lintasan lingkaran dengan jari-jari $\mathrm{r}$, dengan sudut posisi $\theta[14]$.

\section{b) Kecepatan dan laju anguler ( $\omega)$}

Pada gerak melingkar, besaran yang dinyatakan seberapa jauh benda berpindah $(\theta)$ dalam selang waktu $(t)$ disebut sebagai kecepatan anguler atau kecepatan sudut ( $\omega)$.

$$
\omega=\lim _{\Delta x \rightarrow 0} \frac{\Delta \theta}{\Delta t}=\frac{d \theta}{d t}
$$

Satuan kecepatan sudut adalah $\mathrm{rad} / \mathrm{s}$, selain satuan itu dapat pula ditulis rpm (rotation per minute), $1 \mathrm{rpm}=2 \pi$ $\mathrm{radian} / \mathrm{menit}=\pi / 30 \mathrm{rad} / \mathrm{s}$ [15].

\section{c) Periode dan frekuensi}

Periode adalah waktu yang dibutuhkan benda (partikel) untuk menempuh satu putaran penuh. Periode gerak melingkar dapat dinyatakan dengan persamaan sebagai berikut:

$$
T=\frac{t}{n}
$$

Sedangkan frekuensi adalah jumlah putaran dalam waktu satu detik. Sehingga frekuensi gerak melingkar dapat dinyatakan dengan persamaan berikut ini:

$$
f=\frac{n}{t}
$$

Hubungan periode $(T)$ dan frekuensi $(f)$ dapat dinyatakan dengan persamaan (1) dan (2). Sedangkan hubungan kecepatan sudut dengan periode dan frekuensi dapat dinyatakan dengan persamaan sebagai berikut:

$$
\omega=\frac{2 \pi}{T}
$$

atau

$$
\omega=2 \pi f
$$

\section{d) Hubungan kecepatan sudut dan laju linier}

Hubungan kecepatan sudut dengan laju linier dapat dinyatakan dngan persamaan sebagai berikut:

$$
v=\omega r
$$

Karena $\omega=\frac{2 \pi}{T}$, maka

$$
v=\frac{2 \pi r}{T}
$$

\section{e) Percepatan sudut, percepatan linier, dan percepatan sentripetal}

Pada gerak melingkar dikenal tiga besaran percepatan, yaitu percepatan sudut $(\alpha)$, percepatan linier $(a)$, dan percepatan sentripetal $\left(a_{s}\right)$. Percepatan sudut $(\alpha)$ didefinisikan sebagai perubahan kecepatan sudut $(\Delta \omega)$ dalam selang waktu $\Delta t$ dan secara matematis dinyatakan dengan persamaan sebagai berikut:

$$
\alpha=\frac{\Delta \omega}{\Delta t}
$$

dengan $\alpha$ merupakan percepatan sudut $\left(\mathrm{rad} / \mathrm{s}^{2}\right)$.

Kecepatan linier selama geraknya maka partikel tersebut mempunyai percepatan linier yang secara matematis dapat dinyatakan dengan persamaan sebagai berikut

$$
a=r \frac{\Delta \omega}{\Delta t}=r \alpha
$$

dengan $a$ merupakan percepatan linier $\left(\mathrm{m} / \mathrm{s}^{2}\right)$.

Percepatan sentripetal yaitu percepatan benda yang arahnya menuju pusat lingkaran dapat ditentukan dengan persamaan sebagai berikut [16].

$$
a_{s}=\frac{v^{2}}{r}=\omega^{2} r
$$


dengan $a_{s}$ merupakan percepatan sentripetal $\left(\mathrm{m} / \mathrm{s}^{2}\right)$.

\section{Video Based Laboratory}

Video Based Laboratory (VBL) merupakan teknik analisis yang memanfaatkan teknologi komputer untuk menganalisis fenomena atau gejala fisika yang teramati pada rekaman video digital menggunakan software analisis video [17]. Tujuan dari kegiatan pada Video Based Laboratory (VBL) melengkapi siswa dengan alat yang dapat membantunya dalam mempelajari kejadian nyata atau kejadian yang dibuat siswa dapat menganalisis simulasi yang telah tersedia dan fenomena alam, baik sebagai pekerjaan rumah atau di kelas [18].

\section{Tracker dalam pembelajaran}

Adapun manfaat tracker dalam pembelajaran antara lain:

a) siswa dapat mempelajari gerak tertentu secara rinci

b) siswa dapat mengamati berbagai karakteristik gerakan dan mempelajari dasar-dasar fisika klasik dengan cara yang menyenangkan.

c) dapat membantu siswa dalam mempelajari berbagai fenomena gerak dua dimensi

d) memiliki kemampuan untuk melakukan trac (pelacakan) pada gerak suatu objek sehingga dapat diperoleh berbagai informasi yang dibutuhkan dalam gerak dua dimensi

e) melalui tracker, pendidik dan siswa dapat dengan mudah menganalisis permasalahan dunia nyata khususnya pada topik gerak dan optik yang terkadang mustahil dilakukan tanpa bantuan teknologi ${ }^{[19]}$.

\section{Metode Penelitian}

Penelitian ini merupakan jenis penelitian Research and Development (R\&D) tipe 4-D (four-D Model) yang dikemukakan oleh Thiagarajan dan Semmel pada tahun 1974 melalui empat tahap yaitu define (pendefinisian), design (perencanaan), develop (pengembangan), dan disseminate (penyebaran) [20].

\section{Prosedur pengembangan}

Prosedur atau langkah penelitian pengembangan bahan ajar dapat dilihat pada gambar 8 .

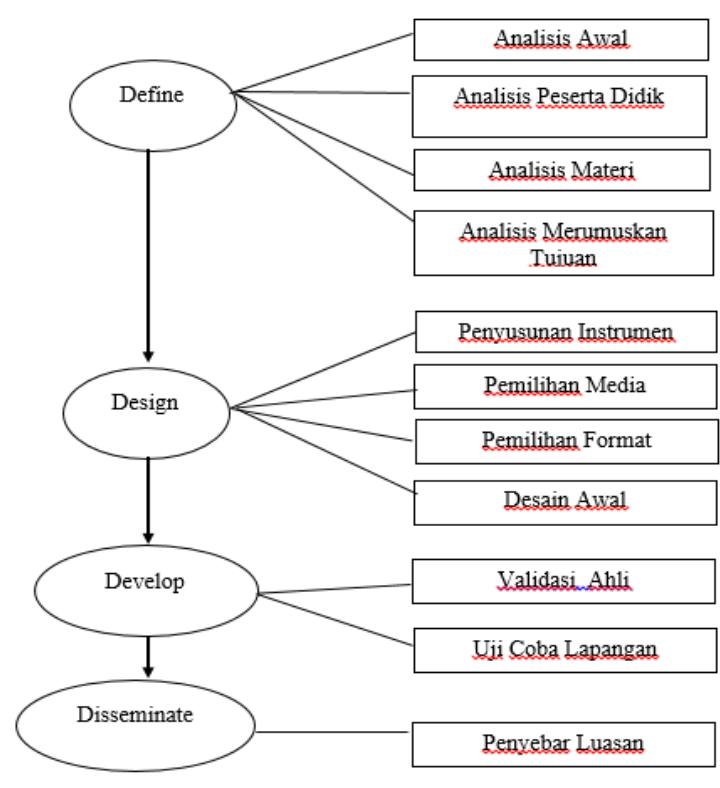

Gambar 8. Bagan penelitian pengembangan

Dari langkah-langkah penelitian tersebut dapat diuraikan secara singkat masing-masing tahap antara lain:

\section{1) Tahap pendefinisian (Define)}

Pada tahap pendefinisian peneliti dapat menetapkan dan mendefinisikan kebutuhan-kebutuhan pembelajaran. Tahap define ini mencakup empat langkah pokok, yaitu analisis awal, analisis peserta didik, analisis materi, dan analisis merumuskan tujuan.

a) Analisis awal

Analisi awal peneliti mencari informasi di lapangan tentang permasalahan yang terjadi dalam pembelajaran fisika. Pencarian informasi dilakukan peneliti dengan cara melakukan observasi lapangan dan wawancara terhadap guru fisika di SMA Negeri 5 Yogyakarta.

\section{b) Analisis peserta didik}

Peneliti melakukan dengan cara observasi di dalam kelas saat kegiatan belajar mengajar berlangsung. Hasil analisis ini akan digunakan sebagai gambaran untuk menyiapkan bahan ajar yang dikembangkan.

c) Analisis materi

Analisis materi dilakukan dengan cara mengidentifikasi materi utama yang perlu diajarkan, mengumpulkan dan memilih materi yang relevan, serta menyusun kembali materi secara sistematis.

d) Analisis merumuskan tujuan

Hal berguna untuk membatasai penelitian supaya tidak menyimpang dari tujuan semula pada saat pengembangan. 


\section{2) Tahap perancangan (Design)}

Tahapan-tahapan yang harus dilakukan pada tahap perancangan ini adalah:

\section{a) Penyusunan instrumen}

Instrumen yang disusun meliputi instrumen validasi bahan ajar berupa buku panduan eksperimen dan CD sebagai bahan eksperimen serta instrumen penilaian hasil uji coba produk.

b) Pemilihan media

Pemilihan media dilakukan untuk mengidentifikasi media pembelajaran yang relevan dengan karakteristik materi dan sesuai dengan kebutahan peserta didik.

c) Pemilihan format

Pemilihan format dilakukan pada langkah awal pengembangan, pemilihan format ini dilakukan agar sesuai dengan materi pembelajaran.

d) Desain awal

Desain awal adalah sebuah rancangan bahan ajar yang telah dibuat oleh peneliti kemudian diberi masukan oleh dosen pembimbing, masukan dari dosen pembimbing akan digunakan untuk memperbaiki bahan ajar sebelum dilakukan produksi.

\section{3) Tahap pengembangan (Develop)}

Tahap ini meliputi validasi bahan ajar oleh para ahli diikuti dengan revisi, kemudian pelaksanaan uji coba. Terdapat dua langkah dalam tahapan ini yaitu sebagai berikut:

\section{a) Validasi ahli}

Validasi Ahli adalah validitas yang berfungsi untuk memvalidasi konten materi Fisika dalam bahan ajar (buku panduan eksperimen fisika dan CD) sebelum dilakukan uji coba dan hasil validasi akan digunakan untuk melakukan revisi produk awal.

b) Uji coba lapangan

Setelah dilakukan validasi ahli kemudian dilakukan uji coba lapangan terbatas untuk mengetahui hasil penerapan bahan ajar dalam pembelajaran di kelas, meliputi respon siswa dan tingkat kelayakan bahan ajar berupa buku panduan eksperimen fisika berbasis video based laboratory dan CD sebagai bahan eksperimen tersebut. Hasil yang diperoleh dari tahap ini berupa bahan ajar yang telah direvisi.

\section{4) Penyebarluasan (Disseminate)}

Tujuan dari tahap ini adalah menyebarluaskan bahan ajar dan pada penelitian ini hanya dilakukan penyebarluasan terbatas, yaitu dengan menyebarluaskan produk akhir bahan ajar secara terbatas kepada peserta didik kelas XI MIPA 1 di SMA Negeri 5 Yogyakarta.

\section{Uji coba produk}

\section{1) Subjek penelitian}

Subjek penelitian ini adalah siswa SMA kelas XI MIPA tahun ajaran 2018/2019 di SMA Negeri 5 Yogyakarta. Pada uji coba ini digunakan 1 kelas siswa.

\section{2) Jenis data}

Dari hasil penelitian jenis data yang diperoleh berupa data primer dari hasil skor validasi dan tanggapan dari ahli materi, ahli media, guru pengguna, dan siswa tentang tanggapan dari panduan eksperimen berbasis Video Based Laboratory menggunakan wahana permainan kanakkanak untuk pembelajaran fisika mekanika.

\section{3) Instrumen pengumpulan data}

(a) Panduan eksperimen berbasis Video Based Laboratory

(b) Lembar penilaian validasi buku panduan eksperimen berbasis Video Based Laboratory

(c) CD berbasis Video Based Laboratory

(d) Lembar angket uji pengguna

\section{4) Teknik analisis data}

Analisis data pada setiap instrumen penelitian ini terdiri dari:

\section{a) Pelaksanaan pembelajaran}

Pengamatan pelaksanaan pembelajaran menggunakan skala Guttman. Skala pengukuran dengan tipe ini, akan didapat jawaban Ya atau Tidak. Dalam sugiyono rumus yang digunakan untuk menghitung persentase dari pengamatan pelaksanaan pembelajaran yaitu [21]:

$$
P=\frac{\sum \text { skor }}{N} \times 100 \%
$$

dengan:

$P=$ angka persen

$\sum$ skor $=$ jumlah skor total yang diperoleh

$N=$ jumlah skor ideal untuk seluruh item

Tabel 1. kategori pemaknaan presentase

\begin{tabular}{cc}
\hline Kategori & Nilai Presentase \\
\hline Ya & $51 \%<N P<100 \%$ \\
Tidak & $0 \%<N P \leq 50 \%$ \\
\hline
\end{tabular}

b) Uji angket

Data yang diperoleh dari pertanyaan-pertanyaan angket merupakan data yang masih kasar belum dikelola. Pada analisis data dilakukan dengan 
mencermati banyaknya centangan yang diperoleh pada kolom jawaban pertanyaan yang berbedabeda nilainya. Skor tiap butir pertanyaan diperoleh dengan menggunakan persamaan sebagai berikut:

$$
P(\%)=\frac{S}{N} \times 100 \%
$$

dengan:

$P=$ tingkat kelayakan $(\%)$

$S=$ jumlah skor total yang diperoleh

$N=$ jumlah skor total maksimum [21].

Tabel 2. Interval nilai dari kelayakan media

\begin{tabular}{cl}
\hline Interval (P) & \multicolumn{1}{c}{ Kriteria tingkat kelayakan } \\
\hline $80 \%-100 \%$ & Sangat layak/sangat baik/sangat setuju \\
$66 \%-79 \%$ & Layak/baik/setuju \\
$56 \%-65 \%$ & Kurang layak/kurang baik/kurang setuju \\
$0 \%-55 \%$ & Tidak layak/tidak baik/tidak setuju \\
\hline
\end{tabular}

Penelitian ini dinyatakan layak apabila didapatkan interval nilai pada $66 \%-100 \%$.

\section{Hasil Penelitian dan Pembahasan}

Hasil penelitian yang telah dilakukan yaitu pengembangan bahan ajar berupa buku panduan eksperimen fisika berbasis Video Based Laboratory menggunakan wahana permainan taman kanak-kanak pada materi mekanika dan $\mathrm{CD}$ sebagan bahan eksperimen. Model pengembangan yang digunakan dalam penelitian ini adalah model pengembangan 4-D.

Tabel 3. Hasil Penelitian Keseluruhan

\begin{tabular}{|c|c|c|c|}
\hline No & & Penguji & Presentase \\
\hline \multirow[t]{3}{*}{1.} & Ahli Materi & Ahli Materi 1 & $95,23 \%$ \\
\hline & & Ahli Materi 2 & $80,95 \%$ \\
\hline & Rata-Rata & & $\mathbf{8 8 \%}$ \\
\hline \multirow[t]{3}{*}{2.} & Ahli Media & Ahli Media 1 & $79,68 \%$ \\
\hline & & Ahli Media 2 & $87,5 \%$ \\
\hline & Rata-Rata & & $83,6 \%$ \\
\hline 3. & Respon Sisv & & $83,79 \%$ \\
\hline 4. & Observasi $\mathrm{p}$ & ksanaan pembelajaran & $100 \%$ \\
\hline
\end{tabular}

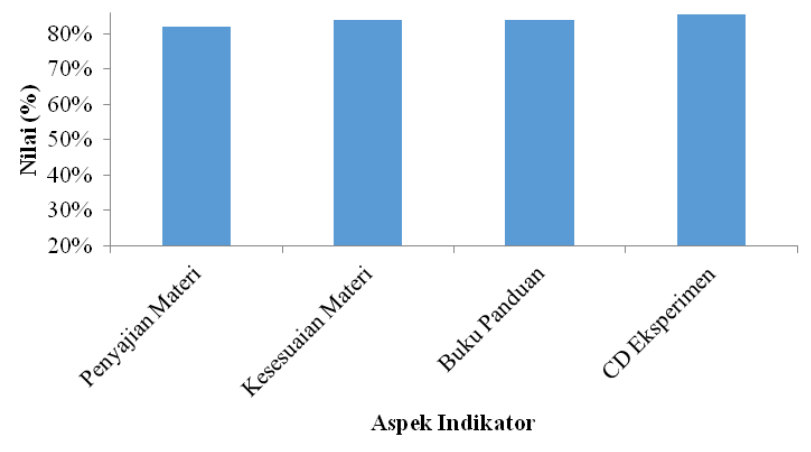

Gambar 9. Grafik hasil uji lapangan

\section{Kesimpulan}

Dihasilkan bahan ajar eksperimen fisika berbasis video based laboratory menggunakan wahana permainan taman kanak-kanak pada materi mekanika untuk siswa SMA Kelas X dan XI. Tingkat kelayakan dari bahan ajar yang dikembangkan memperoleh nilai dari ahli materi $88 \%$ dan ahli media $83,6 \%$, sedangkan respon siswa terhadap bahan ajar memperoleh nilai sebesar $83,79 \%$. Maka dapat disimpulkan bahwa bahan ajar yang dikembangkan sangat layak untuk digunakan sebagai bahan ajar pembelajaran atau panduan dalam melaksanakan eksperimen fisika mekanika berbasis video based laboratory dan mendapatkan tanggapan siswa sangat baik.

\section{Kepustakaan}

[1] A. Yusuf, I. and T. K. Indratno, "Amusement Park Physics in Panggon Lunjak (Trampoline): Analysis of Kinematics and Energy Use Video Tracking," International Journal of Science and Applied Science: Conference Series, vol. 2, no. 1, pp. 32-37, 2017.

[2] A. Prastowo, Panduan Kreatif Membuat Bahan Ajar Inovatif Menciptakan Metode Pembelajaran yang Menarik dan Menyenangkan, Cet-V ed., D. Wijaya, Ed., Yogyakarta: DIVA Press, 2013, p. 16.

[3] R. Maulida and M. P. Simanjutak, "Pengembangan Bahan Ajar Fisika SMA Berbasis Investigasi pada Materi Fluida Dinamis Untuk Meningkatkan Hasil Belajar Siswa," Jurnal Pendidikan Fisika, vol. 4, no. 1, pp. 71-76, Juni 2015.

[4] D. Supriadi, Anatomi Buku Sekolah di Indonesia Problematika Penilaian, Penyebaran, dan Penggunaan Buku Pelajaran, Buku Bacaan, dan Buku Sumber, Yogyakarta: Adi Cita, 2001.

[5] D. C. Giancoli, Fisika, Jakarta: Erlangga, 2001.

[6] D. U. Suwarno, "Getaran osilasi teredam pada pendulum dengan magnet dan batang aluminium," in PROSIDING SKF , Yogyakarta, 2015

[7] P. S. S. Paramita and P. , "Media Pembelajaran Menggunakan Spreadsheet Excel Untuk Materi Osilasi Harmonik Teredam," in Prosiding Seminar Nasional Fisika dan Pendidikan Fisika (SNFPF) Ke-6, Surakarta, 2015.

[8] D. Halliday, R. Resnick and J. Walker, Dasar-Dasar Fisika Versi Diperluas Jilid Satu, Tangerang: Binarupa Aksara, 2015.

[9] P. A. Tipler, FISIKA untuk Sains dan Teknik Edisi Ketiga Jilid 1, Jakarta: Erlangga, 1991.

[10] H. D. Young and R. A. Freedman, Fisika Universitas, Jakarta: Erlangga, 2002.

[11] M. B. Fitriant, D. and I. Syafa'at , "Pengujian Koefisien Gesek 
Permukaan Plat Baja ST 37 pada Bidang Miring terhadap Viskositas Pelumas dan Kekasaran Pemukaan," Jurnal Momentum, vol. 11, no. 1, pp. 13-18, 2015.

[12] P. S. Carvalho and . A. S. e. Sousa, "An Inexpensive Technique to Measure Coefficients of Friction with Rolling Solids," Journal The Physics Teacher, vol. 43, pp. 548-550, November 2005.

[13] B. Purwanto, Fisika, A. S. Wahyudi, Ed., Solo: PT Serangkaian Pustaka Mandiri, 2012, pp. 99-105.

[14] P. Vogt and J. Kuhn, "Analyzing Radial Acceleration with a Smartphone Acceleration Sensor," The Physics Teacher, vol. 51, pp. 182-183, 2013.

[15] D. Halliday, R. Resnick and J. Walker, Fisika Dasar Edisi Ketujuh Jilid 1, Jakarta: Erlangga, 2010.

[16] M. Monteiro, C. Cabeza, A. C. Marti, P. Vogt and J. Kuhn, "Angular Velocity and Centripetal Acceleration Relationship," The Physics Teacher, vol. 52, pp. 312-313, 2014.

[17] I. Pusparagam Teknologi Informasi dan Komunikasi dalam Pembelajaran Fisika, Yogyakarta: LTPS, 2016.

[18] R. Beichner and D. Abbott, "Video-Based Labs for Introductory Physics Courses," JCST, pp. 101-104, 1999.

[19] P. Hockicko, "Development of Key Competencies Using Video Analysis Montions by Tracker," Girep-Efec International Conference, 2011.

[20] L. Prastyawati and F. Hanum, "Pengembangan Model Pembelajaran Pendidikan Multikultural Berbasis Proyek di SMA," Jurnal Pendidikan IPS, vol. 2, no. 1, pp. 21-29, 2015.

[21] S. Metode Penelitian Pendidikan Pendekatan Kuantitatif, Kualitatif, dan R\&D, Bandung: Alfabeta, 2015. 